\title{
Cognitive and emotional effects of occupational stress in nursing professionals*
}

\author{
Efeitos cognitivos e emocionais do estresse ocupacional em profissionais de enfermagem \\ Efectos cognitivos y emocionales del estrés ocupacional en profesionales de enfermería
}

\section{Bruna Paschoalini ${ }^{1}$, Mônica Martins Oliveira ${ }^{1}$, Michele Cândida Frigério ${ }^{1}$, Ana Luiza Ribeiro Pereira Dias ${ }^{1}$, Flávia Heloísa dos Santos ${ }^{2}$}

\begin{abstract}
Objective: Investigating the indicators of stress, anxiety, depression and the cognitive changes in members of the nursing team at Santa Casa de Misericórdia de Assis - SP. Methods: 66 nursing professionals participated in the study, evaluated by psychological and cognitive tracking instruments. Results: The stress experience was not homogenous in the nursing team; high scores in the depression tracking were associated to low cognitive scores. Conclusion: Nursing auxiliaries and technicians were affected by stress. Therefore, worker's healthcare should be provided for the whole nursing team.
\end{abstract}

Keywords: Burnout, professional; Nursing, team; Anxiety; Depression; Neurobehavioral manifestations

\section{RESUMO}

Objetivos: Investigar, de forma integrada, possíveis indicadores de alterações cognitivas, depressão, ansiedade e agentes estressores ocupacionais em auxiliares e técnicos de enfermagem e enfermeiros de diversos setores da Santa Casa de Misericórdia de Assis-SP, por meio de instrumentos de rastreio psicológico e cognitivo. Métodos: Participaram do estudo 66 profissionais de enfermagem, avaliados por instrumentos de rastreio psicológico e cognitivo. Resultados: A experiência de estresse não foi homogênea na equipe de enfermagem; escores altos no rastreio de depressão foram associados a escores cognitivos baixos. Conclusão: Auxiliares e técnicos de enfermagem e enfermeiros foram afetados pelo estresse, portanto, atenção à saúde do trabalhador deve ser oferecida a toda a equipe de enfermagem.

Descritores: Esgotamento profissional; Equipe de enfermagem; Ansiedade; Depressão; Manifestações neurocomportamentais

\section{RESUMEN}

Objetivos: Investigar, de forma integrada, posibles indicadores de alteraciones cognitivas, depresión, ansiedad y agentes estresores ocupacionales en auxiliares y técnicos de enfermería así como de enfermeros de diversos sectores de la Santa Casa de Misericordia de Asís-SP, por medio de instrumentos de rastreo psicológico y cognitivo. Métodos: Participaron en el estudio 66 profesionales de enfermería, evaluados por instrumentos de rastreo psicológico y cognitivo. Resultados: La experiencia de estrés no fue homogénea en el equipo de enfermería; los escores altos en el rastreo de depresión fueron asociados a escores cognitivos bajos. Conclusión: Los auxiliares y técnicos de enfermería y enfermeros se vieron afectados por el estrés por lo que la atención a la salud del trabajador, debe ser ofrecida a todo el equipo de enfermería. Descriptores: Agotamiento profesional; Grupo de enfermería; Ansiedad; Depresión; Manifestaciones neurocomportamentales

\footnotetext{
* Study developed at Santa Casa de Misericórdia in the city of Assis, São Paulo. Results presented in the II Jornada de Saúde no Trabalho at Universidade Estadual Paulista "Julio de Mesquita Filho", Assis, 2007, and at the III Congresso Brasileiro de Psicologia Organizacional e do Trabalho, Florianópolis, 2008.

${ }^{1}$ Psychology scholars at Universidade Estadual Paulista "Julio de Mesquita Filho" - UNESP - Assis (SP), Brazil.

${ }^{2}$ Ph.D, Professor at the Graduate Psychology Department, Universidade Estadual Paulista "Iulio de Mesquita Filho" - UNESP - Assis (SP), Brazil.
} 


\section{INTRODUCTION}

Stress is characterized by an adaptive response of the organism in face of new situations, especially those understood as threatening ${ }^{(1)}$. It is considered an individual process, with variations over the perception of tension ${ }^{(2)}$ and several psychopathological manifestations ${ }^{(3)}$. Within the scope of labor, it can produce several physical, psychic and cognitive symptoms ${ }^{(4)}$, by demanding prolonged adaptive responses, to tolerate, overcome or adapt to stressor agents ${ }^{(5-6)}$, which can jeopardize the individual and the organizations ${ }^{(7-8)}$.

Hospital labor activity is characterized by excessive workload, contact with limit situations, high levels of tension and risks for the healthcare professionals themselves and for others ${ }^{(9)}$. It includes interpersonal relation problems among individuals that provide direct assistance to patients ${ }^{(10)}$ and concerns about institutional demands ${ }^{(11)}$. However, there is no knowledge of studies that investigate, in an integrated way, indicators of cognitive and emotional changes in face of stressor agents that affect the professional exercise in the nursing area.

Authors ${ }^{(12)}$ performed studies with nurses, nursing technicians and auxiliaries working in intensive care units (ICUs), and verified that the main stressing factors reported were the limitations of working conditions and difficulties in interpersonal relations. A possible explanation is that the communication in multidisciplinary teams (nutritionists, psychologists, nurses, physical therapists, pharmacists, dentists and physicians) is marred by difficulties in group action ${ }^{(13)}$, caused by lack of knowledge about the role of the co-workers. Another study ${ }^{(14)}$ indicated that more than half the nurses $(66.7 \%$; $\mathrm{N}=8$ ) presented signs of physical and/or psychological suffering, characteristic of the phase of resistance, which is an intermediate response to stress, between alertness and exhaustion.

Researchers ${ }^{(15)}$ found average tension rates in 73 nurses in public and private hospital emergency units, with higher scores referring to working conditions and personnel administration, showing the necessity of investing in working conditions. This would include the acquisition of ideal quality and quantities of materials, besides hiring enough workers.

Regarding quality of life and depressive symptoms in nursing residents ${ }^{(16)}$, tracked respectively by Beck's Depression Inventory ${ }^{(17)}$ and the SF-36 Quality of Life questionnaire ${ }^{(18)}$, it was concluded that there was a prevalence of dysphoria/depression in $27.9 \%(\mathrm{~N}=68)$ of the nursing residents.

According to Selye's tri-phasic model ${ }^{(19)}$, the effects of stress can manifest in the somatic area, as well as the cognitive area, and appear in increasing sequences and seriousness degrees as the stages of stress aggravate.
In short, the stressor agents in the hospital environment are more closely related to the intrinsic work factors, the professional relations and the organizational structure ${ }^{(20)}$, and can produce physical ${ }^{(4,14)}$ emotional $^{(4,16)}$ and cognitive ${ }^{(4,14)}$ effects. Although specific literature is scarce, the emphasis of the studies lies on the professional exercise, particularly that of nurses, in ICUs and emergency services, so much that little is known about coping with stressor agents in other hospital sectors, or how it happens with the other professionals who make up the nursing team.

The general objective of the present study was to investigate, in an integrated way, possible indicators of cognitive alterations, depression, anxiety and occupational stressing agents in nursing auxiliaries, nursing technicians and nurses from several sectors at Santa Casa de Misericórdia, in Assis - SP, through cognitive and psychological tracking instruments. As its specific objectives, it sought to verify whether: the effects of the stressing agents presented the same characteristics in different hospital sectors; nursing auxiliaries, nursing technicians and nurses have the same perception of the occupational stressing agents; the stressing agents produce cognitive and emotional effects, either associated or independent. This hospital does not provide psychological support to the healthcare professionals, which was one of the factors that determined its selection as the study location.

\section{METHODS}

\section{Ethical Aspects}

The project "Psychobiological aspects in the working environment" respects Resolution \# 196/96 of the National Healthcare Council. It was approved by Conselho de Graduação em Psicologia of Universidade Estadual Paulista, UNESP, campus Assis, on October 07, 2005, and authorized by Conselho Administrativo of Santa Casa de Misericórdia de Assis.

\section{Casuistic}

The institution had 110 employees in the nursing team, of which ten were on leave for health reasons. 80 interviews were performed. However, considering that there were incomplete questionnaires, 66 reports from nursing professionals were included in this study, them being 17 men and 48 women, working in 12/36 shifts, 8 -hour or 6-hour shifts in nine sectors of the hospital: MAT = Maternity, FMC $=$ Female Medical Clinic; PRI $=$ Private, ES = Emergency Services; $\mathbf{M M C}=$ Male Medical Clinic; ORT = Orthopedics; PED = Pediatrics; $\mathbf{M D}=$ Medication Central; $\mathbf{S C}=$ Surgical Center.

\section{Procedure}

Organizational observational visits were performed to obtain and register the information about the hospital 
dynamics and infrastructure. Next, each professional was individually evaluated by an intern during his or her shift, in a single session, for approximately 30 minutes. After a brief structured interview, the tracking instruments were applied randomly. The data from the observations and evaluations were obtained between March and September, 2006.

\section{Tracking instruments}

The Mini-Mental State Examination - MMSE ${ }^{(21)}$ is a brief tracking instrument, which evaluates specific cognitive functions (spatial and temporal orientation, attention, reading, writing, memory and visual constructive capacity) and allows for tracking cognitive dysfunctions with clues of cerebral organicity. It is useful to identify clinical cases according to the gravity (from light cognitive dysfunctions to dementia). Each correct item is scored with 1 point. The score may vary from 0 to 30 points. The cutting point $23 / 24$ has good sensitivity and specificity for the diagnostic of dementia.

Beck's Depression Inventory - BDI ${ }^{(17,22-23)}$ - is a selfreport scale for obtaining of depressive symptoms. Comprising 21 items with a variable intensity of 0 to 3 , about topics such as sadness, pessimism, guilt, suicidal thoughts, irritability, social retraction, indecision, inhibition for work, sleep, fatigue, appetite, libido, etc. A 0-11 score indicates no depression; from 12-19, light depression; from 20-35 grave depression, and from 36 to 63, very grave depression.

State Trait Anxiety Inventory - Inventário Ansiedade Traço Estado - IDATE ${ }^{(24)}$ is a self-report instrument containing two scales: IDATE-S (state); subjective and transitory feelings of tension and IDATE-T (trait); more stable responses (of personality) in face of threatening situations. It comprises 20 items for each scale, with a variable intensity of 0 (never) to 4 (always) and scoring from 20 to 80 points. Resolution 002/2003 from the Federal Psychology Council authorizes its use in scientific research, and recommends the review and updating of normative data.

In the Semantic Verbal Fluency Test, for the category Animals, The participant is asked to say all the names of animals he remembers within a one-minute period. The score is obtained by means of the sum of all correct answers. The average score for individuals with more than 8 years in school would be 15.8 animals ${ }^{(25)}$.

The Nurse Stress Index - NSI ${ }^{(26)}$ investigates stressing agents of the nursing profession. It contains 44 items, with answers varying from 1 (never) to 5 (always). It is comprised of three specific factors: Interpersonal Relations (IR), Stressing Career Roles (SCR) and Factors Intrinsic to Work (FIW). Also, there is a second-order factor, Organizal Structure and Culture (OSC). Each factor can reach a maximum score of 55 points; the total sum of the factors can vary from 44 to 220 points. The higher the scores obtained, the higher the tension ratings in the work environment.

\section{Statistical analysis}

The data obtained were analyzed with the software Statistica for Windows, release 5.0 - Statsoft Inc., 19841999. Averages, standard deviations and response percentages were calculated for descriptive analysis. ANOVA was used for inferential analysis, having as dependent variables the responses (number of correct answers or points) in interview items, test scores and scales; and, as independent variables, the groups (auxiliaries, technicians and nurses). MANOVA was used for the four NSI categories with the same factors among the groups. The contrasts were obtained with the Duncan test and the significance level adopted was $5 \%$. Correlative analyzes were done using Pearson's coefficient ( $r$ ) among the tracking instruments. The moderate correlations $(r>0.40$; $\mathrm{p}<0.05)$ were adopted as minimum scores for discussion.

\section{RESULTS}

\section{Institutional profile}

Through organizational observational, Santa Casa de Misericórdia de Assis - SP, instituted in 1919, was verified to be a philanthropic institution associated with the Single Health System, having 118 beds distributed in 11 clinics. It has a nursing body of 110 people, among active and inactive employees. It performs 600 internments and cares for 3,000 outpatients every month.

\section{Sample profile}

The structured interview made evident that the participants' average age was $33.74( \pm 9.30)$ years old. As for function, there were 40 nursing auxiliaries, 21 nursing technicians and 5 nurses, of whom 74.24 held no other job. For marital status, $56.06 \%$ of the interviewees said that they were married; $54.55 \%$ said they had between one and four children. The average length of time doing their function was 71.28 ( \pm 63.88$)$ months, and the average length of time working at the institution was approximately 4 years and 10 months, varying from 1 to 20 years. There was no group effect regarding the length of time at the function $[\mathrm{F}(2.63)=2.16 ; \mathrm{p}=0.12]$ and the length of time working at the hospital $[\mathrm{F}(2.63)=1.45 ; \mathrm{p}$ $=0.24]$. As for education, 45 professionals had between 10 and 11 years of study, 11 people had between 11 and 12 years of study, and another 10 had up to 15 years of study. There were differences in education $[\mathrm{F}(2.63)=$ 23.73; $\mathrm{p}<0.001$ ], with nurses presenting 15 years of education against 11 years, in average, for nursing auxiliaries and technicians (Duncan; ps < 0.0001). Although the difference was predictable, there were exceptions, in which 
the position held was incompatible with the qualification (four nursing technicians and one nursing auxiliary had university education).

\section{Interview}

In the interview, $81.81 \%$ reported that they consider the profession stressful. Because of this, an ANOVA was performed for repeated measures for the question: "Do you feel more stressed out before, during or after working?" There was no group effect $[\mathrm{F}(2.63)=2.03 ; \mathrm{p}$ $=0.13]$; However, there was a period effect $[\mathrm{F}(2.126)=$ 6.41; $\mathrm{p}=0.002$ ], with the stressors being perceived more frequently during and after working (Duncan, ps < 0.05). Regarding the time of the day they felt more stressed, three participants mentioned that this time was before working; 22, only during work and 21 only after working. The perception of stress during work varied according to the hospital sector: MAT $=50 \% ; \mathrm{FMC}=16 \%$; $\mathrm{PRI}=50 \% ; \quad \mathrm{ES}=75 \% ; \quad \mathrm{MMC}=33 \% ; \quad$ ORT $=50 \%$; $\mathrm{PED}=60 \% ; \mathrm{MC}=60 \% ; \mathrm{SC}=75 \%$. There were cases in which patients chose more than a single alternative. For five of them, stress is felt during the three aforementioned moments, whereas six mentioned not feeling stress at any moment. The remaining subjects oscillated between the three periods. Figure 1 shows the perception of stress per period and professional category.

\section{Tracking instruments}

Table 1 presents the scores obtained per group with the instruments used. There were no differences among the groups for MMSE, IDATE-T, IDATE-S and Verbal Fluency, except for the total NSI score. Next, the NSI items were grouped in four categories of response ${ }^{(17)}$. However, MANOVA did not detect a group effect [Rao $\mathrm{R}(8.118)=1.51 ; \mathrm{p}=0.161]$.

\section{Pearson's Correlation Analysis (r)}

MMSE presented a moderate correlation with the
Semantic Verbal Fluency task $(\mathrm{r}=0.46)$, and a high correlation with the calculation subtest $(r=0.78)$, as well as an internal correlation among the subtests that evaluate verbal memory: immediate and late evocation $(\mathrm{r}=0.45)$. BDI exhibited a positive correlation with IDATE- $\mathrm{T}(\mathrm{r}=$ $0.61)$ and a negative correlation $(r=-0.43)$ with the MMSE subtest Temporal Orientation. IDATE-S presented an internal correlation with IDATE-T $(r=0.49)$. The NSI presented high internal correlations: NSI-IWF $(r=0.86)$, NSI-WR $(r=0.84)$, NSI-CSR $(r=0.89)$ and NSI-OCS $(r=0.94)$.

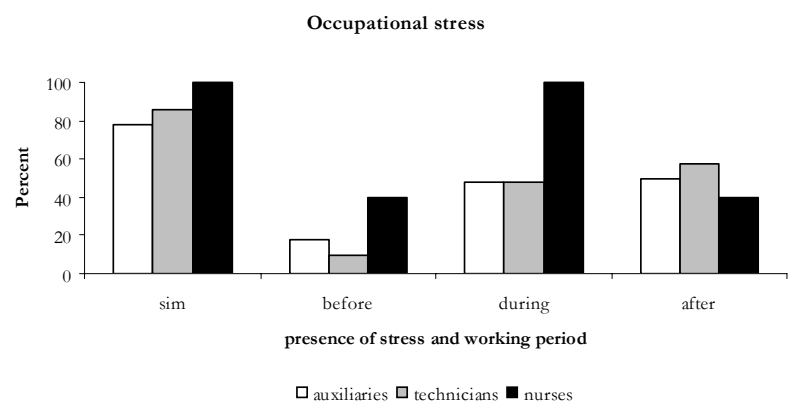

Figure 1 - Percentage of answers of the participants for the questions "Do you consider your profession stressful? If so, when do you feel this stress? (Options: before, during and after work).

\section{DISCUSSION}

The subjective reports of the brief interview were compatible with the quantitative measurements, revealing the presence of subtle damage to the cognitive functions, to humor and of occupational stress. Different indicators were shown to be associated.

Most professionals declared that they considered their profession stressful, and their effects were reported more often to happen during the professional exercise. However, there were exceptions, corroborating studies that state that

Table 1 - Scores [Average (DP)] obtained by nursing professionals in the tracking instruments

\begin{tabular}{lrrrrc}
\hline & \multicolumn{1}{c}{$\begin{array}{c}\text { Auxiliaries } \\
(\mathrm{N}=40)\end{array}$} & \multicolumn{1}{c}{$\begin{array}{c}\text { Technicians } \\
(\mathrm{N}=21)\end{array}$} & \multicolumn{1}{c}{$\begin{array}{c}\text { Nurses } \\
(\mathrm{N}=5)\end{array}$} & \multicolumn{1}{c}{$\mathbf{F}$} & $\mathbf{p}$ \\
\hline Verbal Fluency & $14.72(4.12)$ & $14.90(3.54)$ & $12.60(2.88)$ & 0.748 & 0.477 \\
MMSE (total score) & $29.02(1.98)$ & $29.09(1.56)$ & $29.40(1.51)$ & 0.086 & 0.917 \\
BDI (total score) & $12.35(7.21)$ & $10.14(7.38)$ & $16.40(6.46)$ & 1.667 & 0.196 \\
IDATE-S & $37.90(7.77)$ & $37.90(6.93)$ & $36(3.08)$ & 0.259 & 0.772 \\
IDATE-T & $39.25(10.10)$ & $36.04(9.37)$ & $42(9.02)$ & 1.088 & 0.342 \\
NSI (total score) & $109.53(26.59)$ & $106.09(30.64)$ & $143(19.13) \#$ & 3.755 & $0.028^{* *}$ \\
NSI - IWF & $28.51(6.94)$ & $26.23(7.46)$ & $34.60(5.31)$ & $*$ & \\
NSI - WR & $25.12(6.74)$ & $26.28(9.23)$ & $33.60(6.46)$ & $*$ & \\
NSI - CSR & $25.69(7.69)$ & $23.95(7.29)$ & $33(2.54)$ & $*$ & \\
NSI - OCS & $27.58(7.69)$ & $27.09(10.10)$ & $37.80(6.53)$ & $*$ & \\
\hline
\end{tabular}

$\left(^{*}\right)$ MANOVA $(* *) p<0.05$. (\#) nurses $>$ auxiliaries and technicians (ps < 0.006; Duncan). Legend: Verbal fluency test for the category animals. MMSE: Mini-Mind State Exam; BDI: Beck's Depression Inventory; IDATE = Inventory Anxiety Trait State, E = state and T $=$ trait; NSI = Nursing Stress Index; IWF = Intrinsic Work Factors; OCS = Organizational Culture and Structure; CSR = Career Stressor Roles; WR = Work relations. 
the response to stress is an individual process, and that for some people the perception of tension is higher ${ }^{(2)}$. Besides, in seven out of nine hospital sectors, the reports of stress as happening during the professional exercise surpassed $50 \%$, reaching $75 \%$ in the emergency service and surgical center ${ }^{(15)}$. In the present sample, similar to what happened in other studies ${ }^{(9,15)}$, the stressor agents most often reported were the work conditions and organization. However, it was different from other studies, because interpersonal relations were reported as satisfactory (NSI-WR between 25.12 and 33.6) ${ }^{(10)}$, and work overload due to double shifts was seen in only one third of the respondents ${ }^{(4)}$. People were also observed to perform tasks with demands that were below their qualifications. These facts suggest that the stressor agents have intrinsic characteristics to socioeconomic demands of each city.

As for the cognitive aspects, the MMSE and the Verbal fluency scores were similar to the normative data ${ }^{(21,25)}$, although the calculation and temporal orientation scores were slightly lower. Besides, in the late evocation task, only $50 \%$ of the sample remembered all the items. The chronicity of the state of stress can lower sensibly the cognitive functions and cause cognitive damage ${ }^{(19)}$.

As for the tracking of humor, the average BDI score was under the lower limit for indicators of depression. However, almost one third of the sample obtained scores that were compatible with the classification of dysphoria $^{(16)}$. There was a negative correlation between BDI and one of the MMSE subtests, indicating that high depression scores had been associated to limitations in temporal orientation. In other words, a slight damage to humor was significantly related with subtle effects under cognitive skills, showing and association between cognitive and emotional effects.

As for anxiety, the average values found with IDATE correspond to the Brazilian norms ${ }^{(24)}$ and to a previous study ${ }^{(12)}$, making evident that the professional exercise would not cause high anxiety scores in these professionals, in the trait and state modalities. The correlation between IDATE-T and BDI indicates a similarity between symptoms of anxiety and depression. Therefore, it is recommended that both affective disorders to be tracked among the nursing professionals, and a differential diagnostic to be performed when necessary.

Regarding occupational stress, the NSI scores were similar to normative data ${ }^{(26)}$ and to another study ${ }^{(15)}$, being classified as average. However, the nurses' total score was higher than the score of nursing technicians and auxiliaries, indicating that the labor stressor agents are perceived more intensely by these professionals. The analysis according to specific NSI categories did not detect differences between the groups. It must be considered that the NSI was originally conceived for nurses, and, in this study, was also used for nursing auxiliaries and technicians, whose attributions and responsibilities are different. The physical and psychic symptoms were similar to those reported in literature $^{(12,15,20)}$ and equivalent to those in the NSI.

In short, quantitatively, the levels of anxiety and occupational stressors verified were within normalcy, with the later showing higher scores for nurses. Qualitatively, the working environment was considered stressful by most interviewees, who reported feeling higher effects during their working period. In BDI, the sample average indicates that this was a normal population with a slight tendency to dysphoria. The MMSE scores indicate that the mental functions are preserved, but there is a small difference in the calculation, temporal orientation and memory scores, in association with depression indicators. Nevertheless, these results suggest slight damage, possibly because the sample is still young, with few years of professional exercise and institutional bonding. However, these results are a warning for the risk of graver damage to be made evident in the future if these professionals remain exposed to chronic occupational stress ${ }^{(19)}$.

Considering the objectives of the present study, the research has shown that: the effects of the stressor agents present variable intensities in different sectors of the same hospital; nurses report higher intensities for occupational stressors in relation to nursing auxiliaries and technicians; and still, stressor agents produced associated cognitive and emotional effects.

After the results were presented to Santa Casa de Misericórdia in Assis, the following strategies for health promotion and quality of life were proposed for the nursing team: Educational lectures about stressor agents and how to cope with them; changes in working conditions and rearrangement of workers in the clinics; Opinion polls with the workers to ease the dialogue and improve working conditions; Assignment of one professional to oversee and improve the material logistics in all the clinics; And reevaluating the indicators of cognitive alterations, depression, anxiety and stressor agents in nurses, nursing auxiliaries and technicians six months after these changes are implemented.

\section{CONCLUSION}

Nurses, nursing auxiliaries and technicians are affected by stressor agents. Therefore, the health of the whole nursing staff must be well-cared for.

\section{SPECIAL THANKS:}

To the nursing professionals who participated in the research; To Santa Casa de Misericórdia de Assis - SP, which allowed this study to be performed. To the professor Dr. Sandra Maria Fortaleza and the interns Angélica Nakazone, Ane Fernandes, Bruna Oliveira, 
Daniela Macedo, Letícia Negrizole, Natália Almeida e Vivian Bernardes for helping with data collecton; To Dr.

\section{REFERENCES}

1. Sardá Jr JJ, Legal EJ, Jablonski Jr SJ. Estresse: conceitos, métodos, medidas e possibilidades de intervenção. São Paulo: Casa do Psicólogo; 2004.

2. Da Silva Brito E, Pimenta Carvalho AM. Stress, coping (enfrentamento) e saúde geral dos enfermeiros que atuam em unidades de terapia intensiva e problemas renais. Enfermería Global [ Internet]. 2004 [citado 2007 Dez 11] (4): [aproximadamente 10 p.]. Disponível em: http:/ /www.um.es/ ojs/index.php/eglobal/issue/view/59/showToc

3. Margis R, Picon P, Cosner AF, Silveira RO. Relação entre estressores, estresse e ansiedade. Rev Psiquiatr Rio Gd Sul. 2003; 25(Supl 1): 65-74.

4. Murofuse NT, Abranches SS, Napoleão AA. Reflexões sobre estresse e Burnout e a relação com a enfermagem. Rev Latinoam Enferm. 2005; 13(2):255-61.

5. Couto HA. Stress e qualidade de vida dos executivos. Rio de Janeiro: COP; 1987.

6. Holt RR. Occupational stress. In: Goldberger L, Breznitz S, editors. Handbook of stress: theoretical and clinical aspects. 2nd ed. New York: Free Press; 1993.

7. Cooper CL. Identifying workplace stress: costs, benefits and the way forward. Procedings of the European Conference on Stress at Work; 2003; Brussels: European Foundation for the Improvement of Living and Working Conditions.

8. Moraes LFR, Swan JA, Cooper CL. A study of occupational stress among government white collar workers in Brazil using the occupational stress indicator. Stress Med. 1993; 9:91-104.

9. Elias MA, Navarro VL. A relação entre o trabalho, a saúde e as condições de vida: negatividade e positividade no trabalho das profissionais de enfermagem de um hospital escola. Rev Latinoam Enferm. 2006; 14(4):517-25.

10. Pereira MER. O lazer como aspecto alternativo de alívio de tensão para a equipe de enfermagem em CTI [dissertação]. Ribeirão Preto: Escola de Enfermagem de Ribeirão Preto da Universidade de São Paulo; 1997.

11. Bonato VL. Procura de atendimento psicoterápico pelo trabalhador da saúde. [Dissertação de Mestrado]. São Paulo: Pontifícia Universidade Católica de São Paulo; 1994.

12. Coronetti A, Nascimento ERP, Barra DCC, Martins JJ. O estresse da equipe de enfermagem na unidade de terapia
Jose Javier Berenguer Pina (Universidad de Murcia, Spain), for reviewing the abstract in Spanish.

intensiva: o enfermeiro como mediador. ACM Arq Catarin Med. 2006; 35(4):56-63.

13. Saar SRC, Trevizan MA. Professional roles of a health team: a view of its components. Rev Latinoam Enferm. 2007; 15(1):106-12.

14. Ferrareze MVG, Ferreira V, Carvalho AMP. Percepção do estresse entre enfermeiros que atuam em terapia intensiva. Acta Paul Enferm. 2006; 19(3):310-5.

15. Batista KM, Bianchi ERF. Estresse do enfermeiro em unidade de emergência. Rev Latinoam Enferm. 2006; 14(4):534-9.

16. Franco GP, Barros ALBL, Nogueira-Martins LA. Qualidade de vida e sintomas depressivos em residentes de enfermagem. Rev Latinoam Enferm. 2005; 13(2):139-44.

17. Cunha JA. Manual da versão em português das Escalas Beck. São Paulo: Casa do Psicólogo;2001.

18. Ciconelli RM. Tradução para o português e validação do questionário genérico de avaliação de qualidade de vida "Medical Outcomes Study 36 - item short-form health survey (SF-36)" [tese]. São Paulo: Universidade Federal de São Paulo. Escola Paulista de Medicina; 1997.

19. Selye H. The stress of life. New York: McGraw-Hill; 1984.

20. Stacciarini JMR, Tróccoli BT. O estresse na atividade ocupacional do enfermeiro. Rev Latinoam Enferm. 2001; 9(2):17-25.

21. Brucki SMD, Nitrini R, Carmelli P, Bertolucci PHF, Okamoto IH. Sugestões para o uso do mini-exame do estado mental no Brasil. Arq Neuropsiquiatr. 2003; 61(3B):777-81.

22. Beck AT, Ward CH, Mendelson M, Mock J, Erbaugh J. An inventory for measuring depression. Arch Gen Psychiatry. 1961; 4:561-71.

23. Beck AT, Steer RA. BDI: Beck Depression Inventory Manual. New York: Psychological Corporation; 1993.

24. Spielberger CD, Gorsuch RL, Lushene RE. Inventário de ansiedade traço-stado- idate. Rio de Janeiro: Cepa; 1979.

25. Brucki SM, Malheiros SMF, Okamoto IH, Bertolucci PHF. Dados normativos para o teste de fluência verbal categoria animais em nosso meio. Arq Neuropsiquiatr. 1997; 55(1): 56-61.

26. Stacciarini JMR, Tróccoli BT. Instrumento para mensurar o estresse ocupacional: Inventário de Estresse em Enfermeiros (IEE). Rev Latinoam Enferm. 2000; 8(6):40-9. 